\title{
エロージョンによるセラミックス表面の形態と力学的特性
}

\author{
天田重庚・市村賢司*
}

群馬大学工学部機械システム工学科, 376 桐生市天神町 1-5-1

*富士通(株)基幹通信事業本部交換機事業部，211 川崎市中原区上小田中 4-1-1

\section{Surface Topography and Mechanical Characteristics of Ceramics Roughened by Erosion}

\author{
Shigeyasu AMADA and Kenji ICHIMURA
}

Department of Mechanical Systems Engineering, Faculty of Engineering, Gunma University, 1-5-1, Tenjin-cho, Kiryu-shi 376

*Fujitsu Co., Ltd., 4-1-1, Kamiodanaka, Nakahara-ku, Kawasaki-shi 211

\begin{abstract}
Surface topography and mechanical characteristics of ceramic substrates is very important for the thermal spraying for solid oxide fuel cells. Usually, surfaces are eroded by blasting before thermal spraying to increase the adhesive strength of coatings. The erosion tests were performed for three kinds of commercial ceramics $\left(\mathrm{Al}_{2} \mathrm{O}_{3}\right.$, machinable ceramics: MACOR, glass) with changing impingement velocity and time. The eroded surfaces were evaluated by average surface roughness $\left(\boldsymbol{R}_{\mathrm{a}}\right)$, fractal dimension $(\boldsymbol{F}$. D.) and wear volume based on Evans' theory. It was concluded that the relations between effective wear rate and eroded surface topography depend on the crack types, and fractal dimension increases with fracture toughness of ceramics.

[Received July 15, 1996; Accepted November 12, 1996]
\end{abstract}

Key-words : Erosion, Surface topography, Fractal dimension, Surface roughness, Structural ceramics

\section{1. 緒 言}

高効率の次世代発電システムとして燃料電池が有望視されて いる. その中で，固体電解質型燃料電池は最も期待できる1),2). 固体電解質型の燃料電池では，セラミックス基盤上に電極セラ ミックスを積層させる必要がある3)。プラズマ溶射でこれを形 成する過程にて, 両者の密着性が問題となってくる.この密着 性は両者の界面の粗面形態が重要な役割を演ずる。一般に，金 属に対しては, 粒子を高速で衝突させ, 塑性变形によって表面 を粗面化するブラスト加工4)が行われている，一方，セラミッ クスのブラスト加工では, 粒子衝突による表面層の破壊・はく 離によるエロージョン摩耗によって粗面が形成される。それゆ え, エロージョン摩耗と加工された粗面形態との関係は重要で ある。

一方, エロージョンは Wiederhorn ${ }^{5)}$, Evans $^{6)}$, Wada $^{7)}$, 秋 宗8)らによって単一粒子衝突による問題が研究された. 特に, 衝突粒子の運動エネルギー, 材料物性, 標的々なる試料の材料 物性が摩耗にに゙のように影響を及ぼすか，あるいは摩耗機構の 解明に主眼が置かれた。しかし，多数粒子衝突によって形成さ れた粗面の形態特性の研究はほとんど行われていない。そこ で, 本研究はエロージョン摩耗によって, セラミックス基盤上 に形成される粗面の形態特性を表面粗さ，Mandelbrotによっ て確立されたフラクタル幾何学 ${ }^{9}$, Evans の理論等から評価す
るものである。

\section{2. ブラストによる粗面加工}

標的となる試験片材料は $\mathrm{Al}_{2} \mathrm{O}_{3}$, パイレックスガラス, ガラ スとセラミックスの中間的なマシナブルセラミックス（商品 名; $\mathrm{MACOR}$ (マコール): $\mathrm{SiO}_{2}(46 \%)+\mathrm{MgO}(17 \%)+\mathrm{Al}_{2} \mathrm{O}_{3}$ $\left.(16 \%)+\mathrm{K}_{2} \mathrm{O}(10 \%)\right)$ を選び, $25 \mathrm{~mm}$ 角, 厚さ $5 \mathrm{~mm}$ の板試 験片を採用した。それぞれの材料の関係する物性值を図 1 に示 す。

ブラスト加工は図 2 に示すようにノズル部より粒子を噴出さ

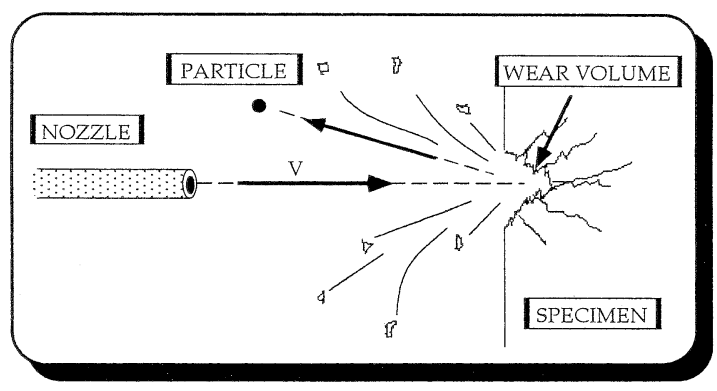

Fig. 1. Erosion (Blasting) process.

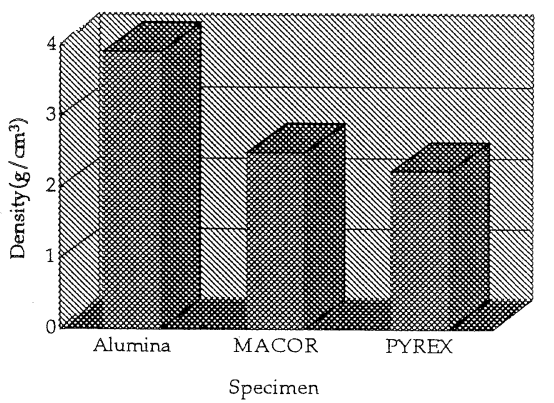

(a) Density

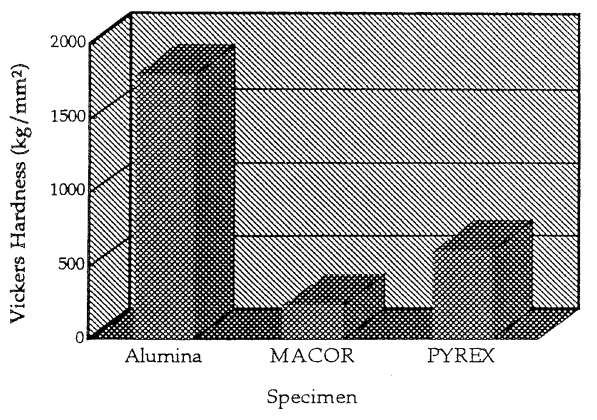

(b) Hardness

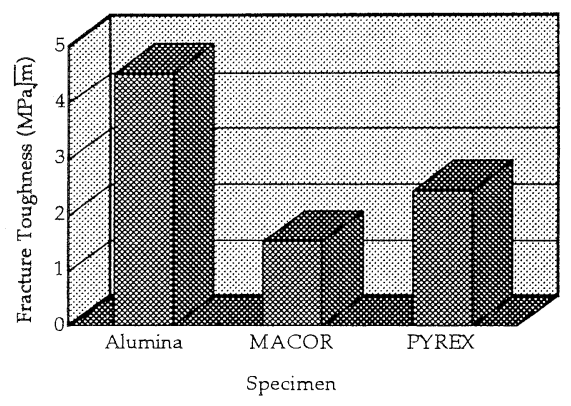

(c) Fracture toughness

Fig. 2. Material properties of specimens. 


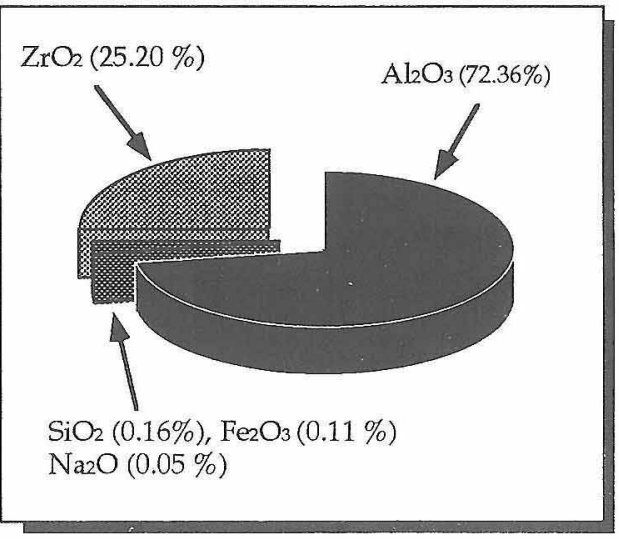

Fig. 3. Constituents of grit.

Table 1. Basic Blasting and Pressure Conditions (a) Basic Blasting Conditions, (b) Pressure Conditions.

(a)

\begin{tabular}{c|c}
\hline Type & Pressure type \\
\hline Grit & $\mathrm{AZ}-73(\# 20)$ \\
\hline Pressure & $0.098 \sim 0.49(\mathrm{MPa})$ \\
{$\left[1 \sim 5\left(\mathrm{kgf} / \mathrm{cm}^{2}\right)\right]$} \\
$0.15(\mathrm{~m})$ \\
Distance \\
Degree & $90 \quad($ degree $)$ \\
Time & $0 \sim 200(\mathrm{sec})$ \\
\hline
\end{tabular}

(b)

\begin{tabular}{c|c|c}
\hline Specimen & Pressure & Time (s) \\
\hline $\mathrm{Al}_{2} \mathrm{O}_{3}$ & $0.49(\mathrm{MPa})$ & $30,60,120,200$ \\
\hline MACOR & 0.196 & $1,3,5,7$ \\
\hline & 0.294 & $0.5,1,3,5$ \\
\hline & 0.49 & $0,5,1,3,5,7$ \\
\hline PYREX & 0.098 & $1,3,5,10$ \\
\hline & 0.196 & $1,3,5,7$ \\
\hline
\end{tabular}

せ，標的となる材料表面を摩耗，粗面化する技術で，衝突粒子 として井20（平均粒径：約 $0.92 \mathrm{~mm}$ ) のグリットを用いる. 成 分は図 3 に示守ように $\mathrm{Al}_{2} \mathrm{O}_{3}(75 \%), \mathrm{ZrO}_{2}(25 \%)$ 加ら主に構 成されている。これを表 1 (a)に示すような基本的の条件と， (b)に示すような压力と時間にてプラスト加工を行う。 $\mathrm{Al}_{2} \mathrm{O}_{3}$ は摩耗しにくい材料であること, 本装置の最大圧力が $5 \mathrm{~kg} /$ $\mathrm{cm}^{2}$ 等の理由から一種類の圧力のみの実験となった。

\section{SEM による表面観察}

これまで知られている粒子衝突によるエロージョン摩耗機構 は, (a)リング, コーン (ヘルツ), ラジアル,メジアン, ラテ ラルクラックの発生とそれらによるはく離，(b) (a) からの粒 界き裂による結晶粒の脱落，(c)引っかき，(d)表面凸部の粒 子による衝突圧砕，等で方る。

図 4 はガラスの表面走査型電子顕微鏡（SEM）写真である。 表面は，結晶粒界が存在しないため，ガラ久特有の平滑（ミ ラー）曲面とその外側に形成される粗な（ミスト）面と，主に 衝突によるき裂が分岐してできる凹凸の激しい（Hackle）面 (a)

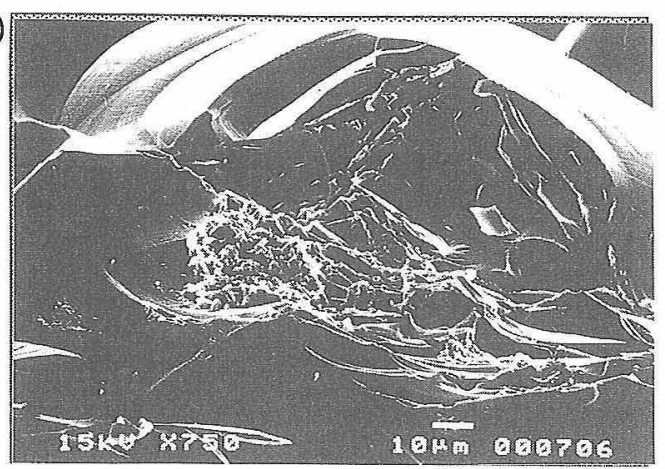

(b)

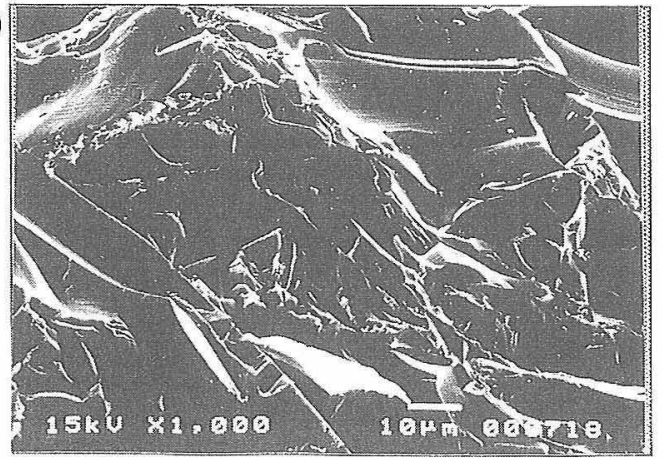

Fig. 4. Eroded surfaces of glass. (a) Pressure: $0.098 \mathrm{MPa}$, time: 1s. (b) Pressure: $0.098 \mathrm{MPa}$, time: $10 \mathrm{~s}$.
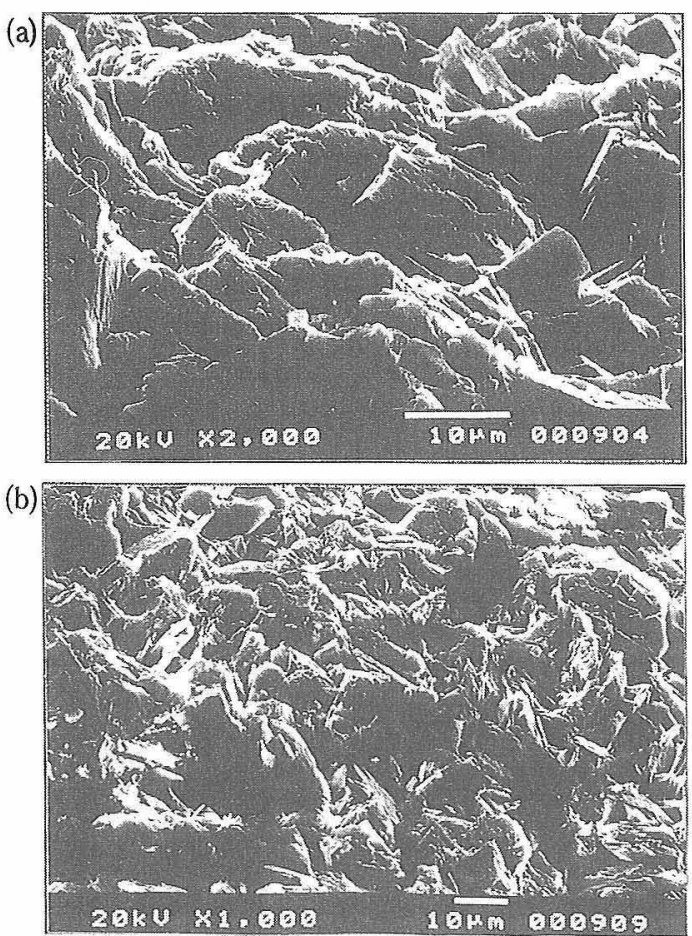

Fig. 5. Eroded surfaces of MACOR. (a) Pressure: $0.196 \mathrm{MPa}$, time: 1s. (b) Pressure: $0.196 \mathrm{MPa}$, time: $7 \mathrm{~s}$.

から構成されている，摩耗はラテラルクラック等によって進行 し，図 4 (a)と (b) を比較すると，ブラスト時間が増加するに つれて，粒子衝突数が増えることで，細かい破面が形成されて いる.

MACOR の表面を図 5 に示す，ガラス成分を多量に含む材 料であり，はく離は主にラテラルクラック等によるものと推察 されるが，一部は粒界き裂によるものが観察される.ブラスト 
(a)

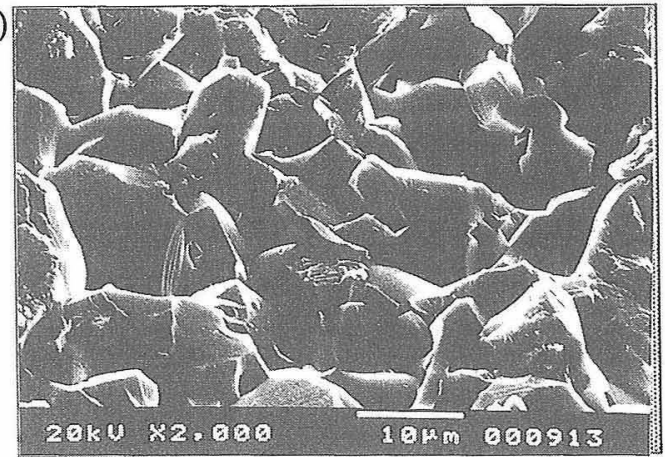

(b)

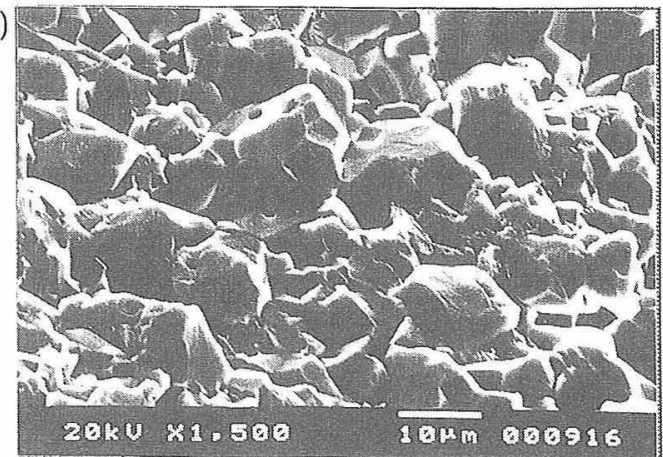

Fig. 6. Eroded surfaces of $\mathrm{Al}_{2} \mathrm{O}_{3}$. (a) Pressure: $0.49 \mathrm{MPa}$, time: 30s. (b) Pressure: $0.49 \mathrm{MPa}$, time: $200 \mathrm{~s}$.

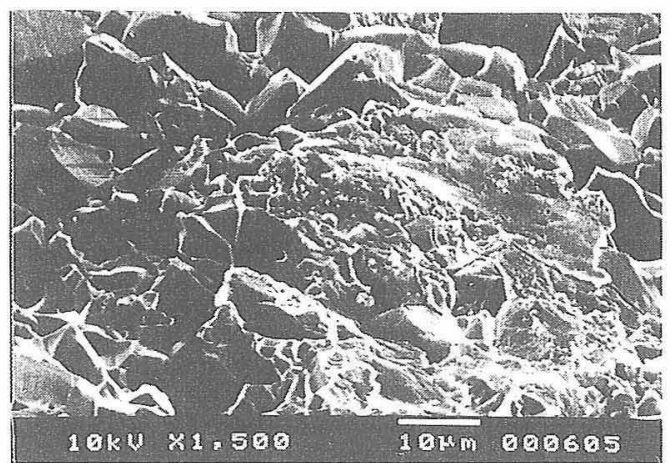

Fig. 7. Partially melted surface of $\mathrm{Al}_{2} \mathrm{O}_{3}$ (Pressure: $0.49 \mathrm{MPa}$, time: 200s).

時間の増加とともに，破面も細かくなる.

図 6 は $\mathrm{Al}_{2} \mathrm{O}_{3}$ の場合で，前二者に比較して細かい凹凸の破 面を呈する．摩耗は最終的に粒界に生じたき裂により結晶が脱 落して進行すると推察されるが，一部は衝突粒子の王砕による 部分が見られる。なた，図７に見られるように粒子が衝突によ ク一度溶融し，再び固化した部分も観察される．このような現 象は Ritter10)や他の研究に捂いても報告されている。

\section{4. エロージョン摩耗}

単一粒子の衝突によって標的試料面にラテラルクラックが生 じ，材料がはく離すると仮定する．Evans ら゙のによとここの 摩耗量 $V_{\mathrm{e}}$ は

$$
V_{\mathrm{e}} \propto v^{19 / 6} R^{11 / 3} \rho^{19 / 12} H^{-1 / 4} K_{\mathrm{IC}}{ }^{-3 / 4}
$$

のように与えられる.ここで， $R, v, \rho$ 疅突粒子の半径, 速 度, 密度である. $H$ と $K_{\mathrm{IC}}$ は標的の硬さと破壞勒性値である。 本実験では同一グリットを使用するので，(1)式は次のように 書き換えることができる。

$$
V_{\mathrm{e}} \propto v^{19 / 6} H^{-1 / 4} K_{\mathrm{IC}^{-3 / 4}}
$$

それゆえ（3)式を計算するには図 2 のデータと衝突粒子の速 度 $v$ が必要となる，本実験で使用したブラスト装置では粒子速 度の測定が困難なので，流速 $V_{g}$ の噴流気体中の単一粒子の運 動方程式 ${ }^{11)}$,

$$
\frac{\mathrm{d} v}{\mathrm{~d} t}=\frac{3}{8} \frac{C_{\mathrm{D}}}{R}\left(\frac{\rho_{\mathrm{g}}}{\rho}\right)\left(V_{\mathrm{g}}-V\right)\left|V_{\mathrm{g}}-V\right|
$$

を解いて, 粒子の速度を推定した. ただし， $C_{\mathrm{D}}$ は抗力係数, $\rho_{\mathrm{g}}$ は気体の密度である. 図 8 にその計算結果を王力に対して 示す。こ扎より，粒子速度は気体の約 $40 \%$ ぼであることが 分加る。

図 9 にブラスト時間に対する摩耗重量の測定結果を示す。摩

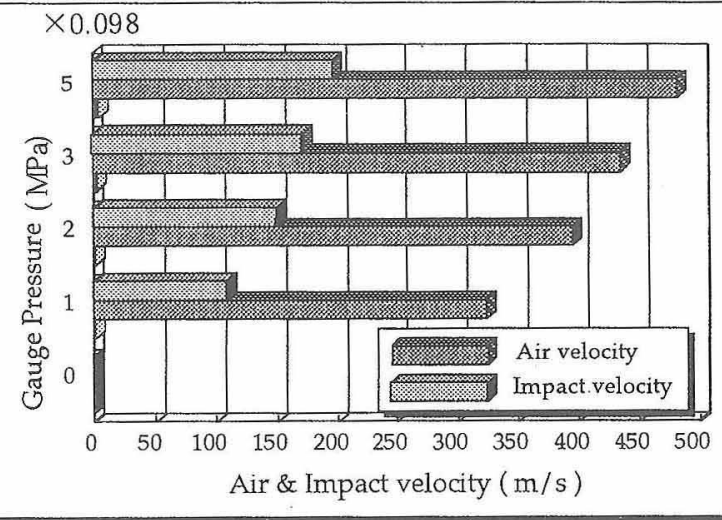

Fig. 8. Calculated impact velocity

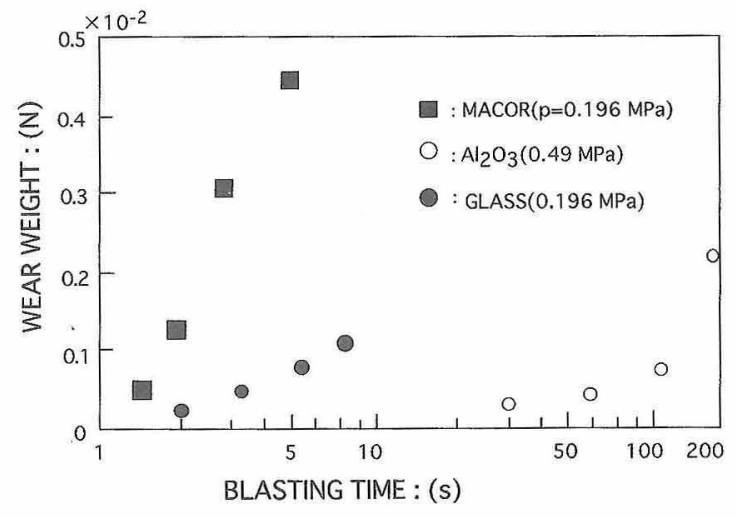

Fig. 9. Wear weight with time.

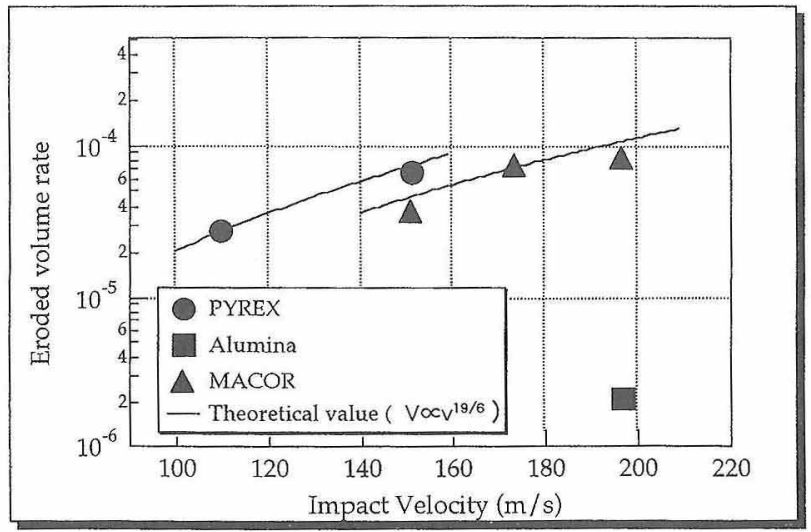

Fig. 10. Eroded volume rate with respect to particle velocity. 


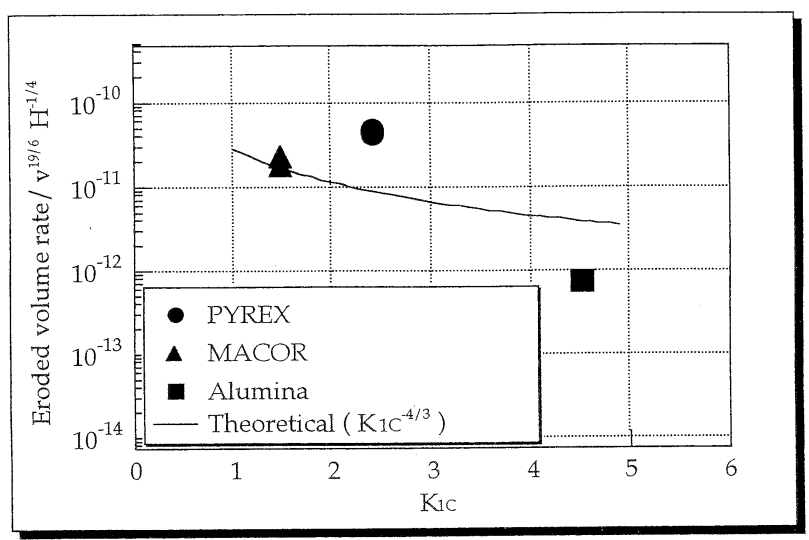

Fig. 11. Eroded volume with respect to $K_{\text {IC }}$.

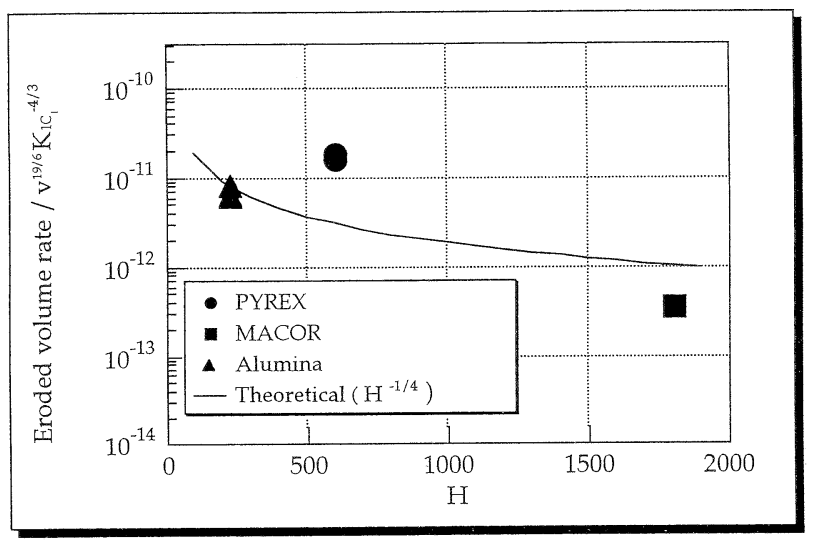

Fig. 12. Eroded volume rate with respect to hardness.

耗量は時間とともに増加するが，その割合は材料によって著し く異なることが分かる。増加の特性や絶対值自身は，それぞれ の材料によって異なっている. 摩耗率の算出は, これらの曲線 の勾配より求めた。

(2)式を多数粒子の衝突によるエローショョン摩耗に拡張す る.この場合, 絶対値の正確な評価は難しいが, 種々のケース の相対評価は可能であろう. 図10は摩耗率に対する粒子速度の 関係で, 変圧の実験なしの $\mathrm{Al}_{2} \mathrm{O}_{3}$ を除いて, 実線の (2) 式に良 く一致している. 図11は $K_{\text {IC }}$ に対する摩耗率の関係で, 測定 結果の傾向は実線の(2)式に近い。 また，図12は摩耗率と硬さ との関係であり，これも両者は近い值を示している.

\section{5. 表面粗さ}

表面のトポグラフィー特性として平均表面粗さを, 触針式の 粗さ計にて測定した。図13, 図14, 図15に三種類の材料の, ブ ラスト時間に対して氏カをパラメーターとして平均表面粗さを 示す。いずれの材料に打いても，表面粗さは時間とともに飽和 している.この傾向は, 金属のブラスト加工の場合と非常に良 く一致する. 金属の場合が, 粒子の衝突の塑性変形による加工 硬化に基づくものである，一方，セラミックスの場合は顕著な 塑性変形挙動を示さない。粗面は, 初期に処女面が時間ととも に粒子の衝突によって覆われる面積が増加する，このとき，表 面粗さも増加するが, 完全に衝突面が表面を覆うと, 粗面特性 は粒子の衝突による材料のはく離・脱落過程に支配され，時間 に関係しなくなる。また，飽和後に表面粗さが若干低下してい

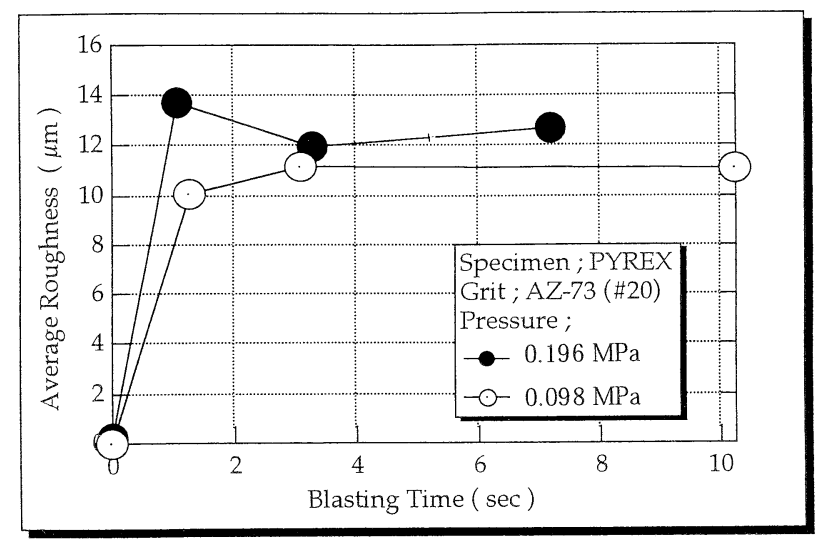

Fig. 13. Change of average roughness with blasting time for glass.

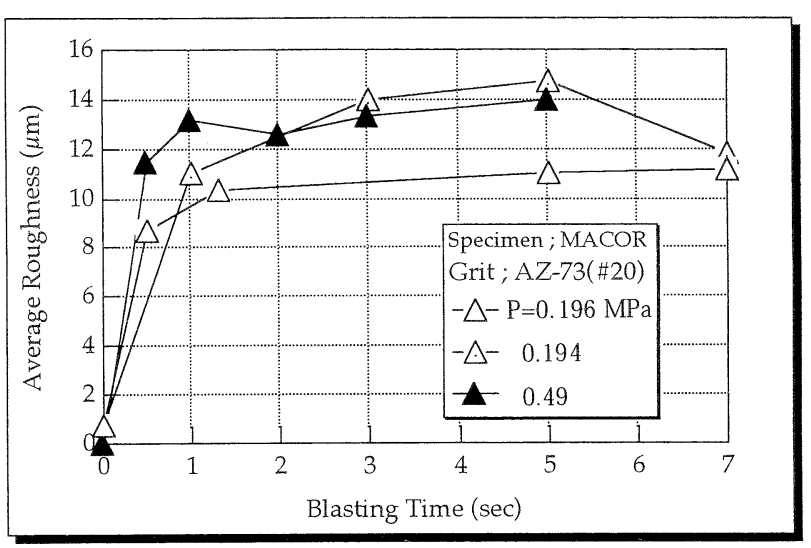

Fig. 14. Change of average roughness with blasting time for MACOR.

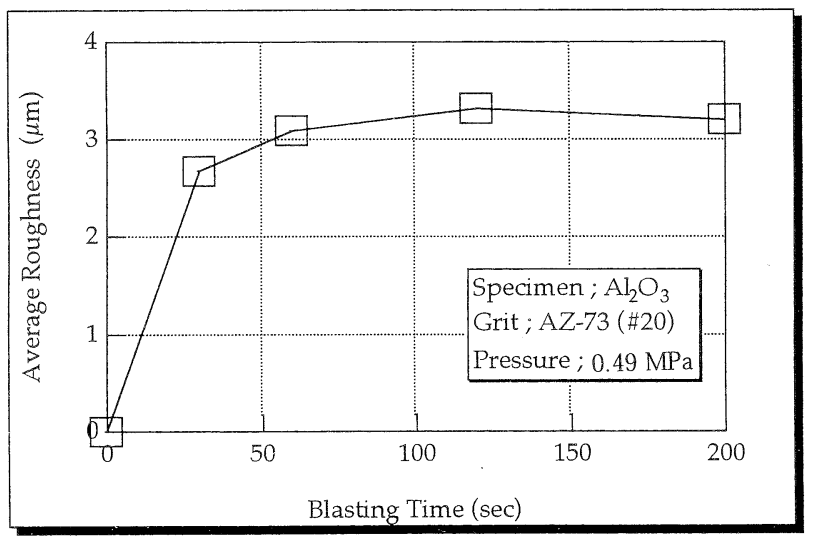

Fig. 15. Change of average roughness with blasting time for $\mathrm{Al}_{2} \mathrm{O}_{3}$.

るのは, 粗面の突起部が圧砕によって, 脱落するものと推察さ れる. 金属における“オーバーブラスト”に相当する.

最大の表面粗さはガラスが約 $12.0 \mu \mathrm{m}, \mathrm{MACOR}$ が $11.8 \mu \mathrm{m}$, $\mathrm{Al}_{2} \mathrm{O}_{3}$ が $3.3 \mu \mathrm{m}$ となる. 表面粗さは, 一回の粒子衝突によっ て生じるき裂の大きさに支配されるので, 粒界のないガラスで はき裂の折れ曲がりがないので，大きな粗面が形成される。一 方, $\mathrm{Al}_{2} \mathrm{O}_{3}$ では粒界き裂によって主に摩耗が進行するので, 図 から分かるように, 粗さは結晶粒のオ一ダーとなる. 


\section{6. フラクタル解析}

非整数次元を有するフラクタル幾何学は, 複雑さを表す指標 として種々の分野への展開が計られている。そこで，粗面の卜 ポグラフィー特性として, 粗面の複雑さをフラクタル次元を用 いて評価する。粗面のフラクタル次元は溶射皮膜の密着性と密

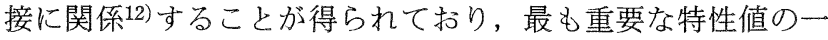
つである。

図16に測定システムを示す。試験片を顕微鏡下に置き, CCD カメラにて画像処理ボードを通して計算機に取り込む。 この画像から二值化処理を施して表面プロファイルを決定す る. フラクタル次元の評価法はいくつかあるが，ここではボッ クスカウンティング法13)を用いる。すなわち，さきに決定し た表面プロファイルの平面を，図17に示すように一辺が $d の$ 正方形で覆う．このとき，プロファイルを含むか，接触してい る正方形の個数 $N$ を数える. 次に正方形の大きさを変え, 再 度 $N$ を数える.この手順を反復して $d$ と $N$ の関係を求める. フラクタル幾何学は

$$
N(d) \propto d^{-D}
$$

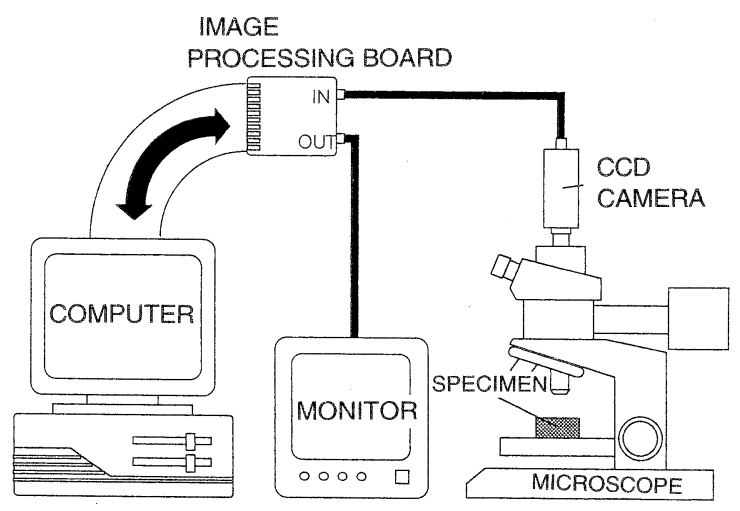

Fig. 16. System of image analysis.

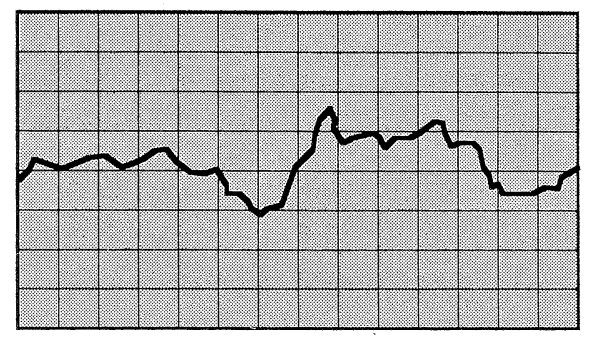

Fig. 17. Box counting method.
なる関係を与える．ここで， $D$ はフラクタル次元を意味する. 比例係数を $\mu(>0)$ とし, 両辺の自然対数をとれば,

$$
\log N(d)=-D \cdot \log d+\log \mu
$$

となる。（5)式は両対数平面上の $N-d$ 関係は直線となり，その 勾配がフラクタル次元を与えることを意味している.

図18(a), (b), (c)に三種類の材料の $\log N-\log d$ プロットを 示す.いずれのプロットも直線関係を示して抢り, エロージョ ンによる粗面はフラクタル性を持つことが分かる。これらの直 線の勾配がフラクタル次元を表す。に゙の材料でも1.1前後であ り，良く知られた三角形分割から形成されるコッホ曲線の次元： 1.262 から比較して低い值となっている．金属材料のブラスト 粗面では, 最大で1.094 ${ }^{12)}$ の值となるから，セラミックスでは いくぶん高い次元を持つ。

試料表面の異なる60個所を選び，これらのデータの平均值 を用いて図19にガラスと MACOR のブラスト時間〜フラクタ ル次元曲線を，図20に $\mathrm{Al}_{2} \mathrm{O}_{3}$ の場合を示す。いずれの場合も

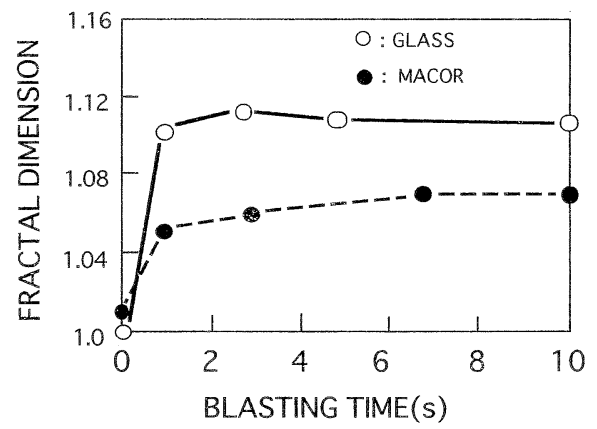

Fig. 19. Fractal dimension with blasting time for glass and MACOR.

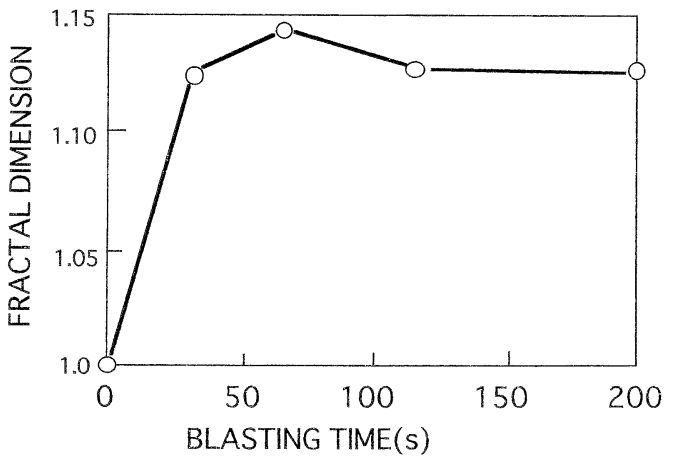

Fig. 20. Fractal dimension with blasting time for $\mathrm{Al}_{2} \mathrm{O}_{3}$. (a)

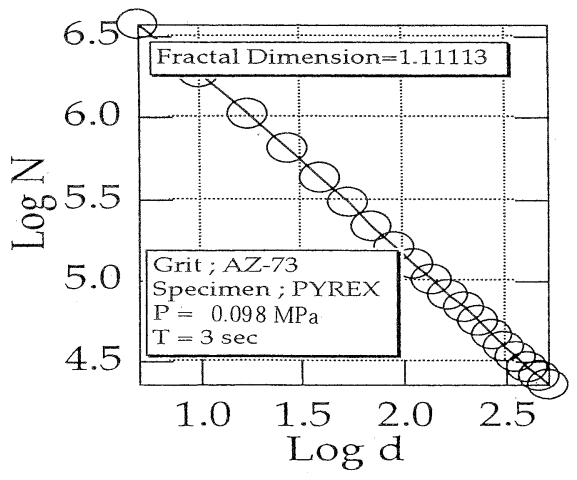

(b)

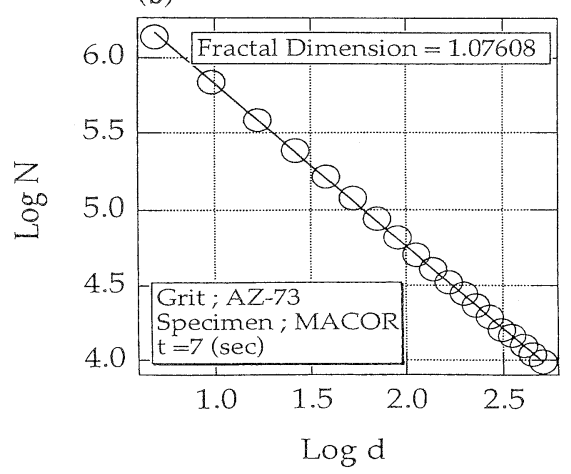

(c)

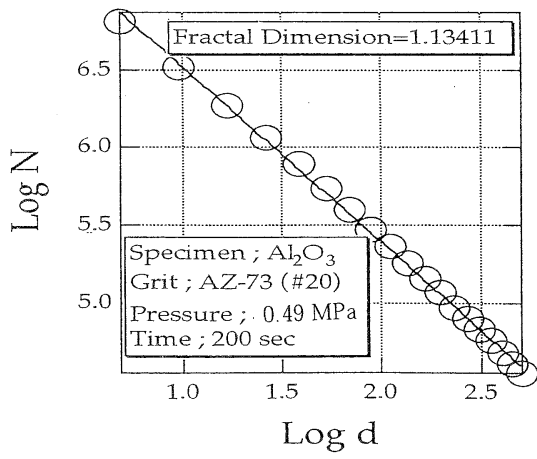

Fig. 18. $\log N-\log d$ plots of sampled surfaces. 


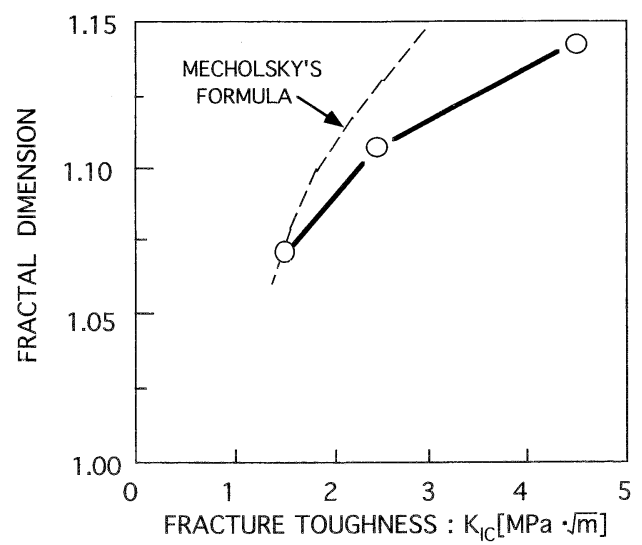

Fig. 21. Fractal dimension with fracture toughness $K_{\mathrm{IC}}$.

時間とともに飽和する傾向を持つ。最大の次元は $\mathrm{Al}_{2} \mathrm{O}_{3}$ で 1.14 , 次いでガラス, MACORの順となった。 フラクタル次 元が大きいと粗面が複雑度が大きくなるわけだが，これは破壊 面のき裂の大きさに支配されると考えられる。 $\mathrm{Al}_{2} \mathrm{O}_{3}$ の場合は き裂が粒界をジグザグに進むので次元が高く，ガラスや MACOR で低いのはき裂が直進するために破面が単純な曲線 になるためと思われる。

図21にフラクタル次元と破壊勒性值との関係を示す。破壊勒 性值が大きくなると次元の值も増大する傾向にある. Mecholsky ら ${ }^{14)}$ は数種類のアルミナ, ガラスセラミックスについて破 壊試験時の破面のフラクタル解析を行い, フラクタル次元と

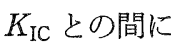

$$
K_{\mathrm{IC}}=A \cdot D^{* 1 / 2}
$$

なる関係があることを導いた。ただし， $A$ は定数， $D^{*}$ はフラ クタル次元の少数点以下の值である. $D^{*}$ とヤング率や粒径と の間にはあまり相関がみられないとしているが，材料が限られ ているなどの点で問題を残していた．その後, Mecholskyと Freiman ${ }^{15)}$ は他の研究結果である PZT, ZnS, ZnSe, WC-Co, 等の材料も含めて検討した結果, 近似的に(6)式が成立するこ とを示した。（6）式を図21に点線で示す。本実験結果は， Mecholsky らの結果と比較すると低い值となっている。この 差は，本結果が粒子衝突によるエロージョン破面であることに 起因すると推察される. Mecholsky ら14) も述べているように, 破壊勒性值が増加するとき裂パスが直線からはずれ，曲がりく ねった経路をたどることから, 破面の複雑さが増加し, フラク タル次元の増加につながると推論できる.

\section{7. 結 論}

ガラス, MACOR, $\mathrm{Al}_{2} \mathrm{O}_{3}$ の三種類の材料に対し, エロー ジョン摩耗であるブラスト加工を施し, エロージョン特性, 表 面粗さとフラクタル次元を用いて表面トポグラフィー特性を評 価し，次のような結論を得た。

（1）摩耗量は時間とともに増加するが，その割合は材料の 物性に依存する. ラテラルクラック生成に基づくEvans の理 論は実験結果と近似的に一致する.

（2）平均表面粗さは初期に増加するが，ある時間が経過す ると飽和する.この特性は, 塑性加工による金属のブラスト加 工面の粗さ-時間曲線の傾向と一致する. なた，飽和する時間 は摩耗速度に密接に関係する。

（3）フラクタル次元は時間とともに増加するが，その後は 飽和する. 次元の大きさは材料の破壊勒性值の増加とともに高 くなる.これは, 勒性值の高い材料の破面が, ジグザグ状に進 むき裂進展によって形成されることによるものと推察される。

謝 辞 本研究は1994年度科学研究費補助金 (一般研究 (C); 課題番号06650126）「高フラクタル次元界面を持つ溶射皮膜の形 成に関する研究」の一部として実施したものである.

(1995年 4 月日本セラミックス協会年会講演会にて発表)

\section{文献}

1）田川博章, 日本機械学会誌, 94, 81-85 (1991).

2) 岩本啓一, 宮本 均, 吉田行男, 久留長生, 南條房倖, 三菱 重工技報，32, 31-37 (1995)。

3）村上信明, 石橋 勝, 長田 勇, 吉田行男, 内田 聡, 南條 房幸，三菱重工技報，29，182-87（1992）。

4）長坂秀雄，溶射技術，30, 12-19 (1993).

5) S. M. Wiederhorn and B. R. Lawn, J. Am. Ceram. Soc., 60, 458-61 (1977).

6) A. G. Evans, M. E. Gulden and M. Rosenblaff, Proc. Royal Soc. London, Ser. A, 361, 343-65 (1978).

7) S. Wada, "Erosion of Ceramic Materials", Ed. by J. Ritter, Trans Techno Publ. (1992) pp. 57-74.

8）秋宗淑雄, 䅖場 亨, 岡本祐介, 広崎尚登, J Ceram. Soc. Japan, 102, 653--57 (1994).

9) B. B. Mandelbrot, "The Fractal Geometry of Nature", Freeman (1982).

10) J. E. Ritter, "Erosion of Ceramic Materials", Ed. by J. E. Ritter, Trans Tech Publ. (1992) pp. 107-20.

11) N. El-Kaddah, J. Mckelliget and J. Szekely, Metallurugical Transaction, 15B, 59-70 (1984).

12) S. Amada and H. Yamada, Surface Coatings \& Technology, 78, 50-55 (1996).

13）高橋秀樹, “フラクタル”, 朝倉書店 (1989) pp. 10-13.

14) J. J. Mecholsky, D. E. Passoja and K. S. Feinberg-Ringel, J. Am. Ceram. Soc., 72, 60-65 (1989).

15) J. J. Mecholsky, Jr. and S. W. Freiman, J. Am. Ceram. Soc., 74, 3136-38 (1991). 